References

1 Howard-Peebles PN, Yarbrough K, Stoddard GR. Partial trisomy of chromosome 15. Am J Ment Defic 1977;81:606-9.

2 Coco R, Penchaszadeh VB. Inherited partial duplication deficiency of chromosome 15. J Genet Hum 1978,26: 203-10.

3 Taysi K, Devivo DC, Sekhon GS. Partial trisomy 15 and intractable seizurcs. Acta Paediatr Scand 1979;68:445-7.

4 Seabright M. A rapid banding technique for human chromosomes. Lancet 1971 ;ii:971-2.

Requests for reprints to Dr S Coldwell, Department of Paediatrics, Royal West Sussex Hospital, St Richard's, Spitalfield Lane, Chichester, West Sussex PO19 4SE.

\section{Congenital dislocation of the knees in a child with Down-mosaic Turner syndrome}

SUMmARY A further case of Down-mosaic Turner syndrome is discussed. Both the cytogenetic and the dermatoglyphic data support the clinical diagnosis. The association with dislocated knees and the diagnosis of this polysyndrome at birth have not been reported before.

Approximately one in 200 liveborn children have a chromosomal abnormality. ${ }^{1}$ It appears that aneuploidy and structural chromosomal anomalies are among the most common causes of abnormal fetal development. Klinefelter syndrome with Down syndrome is the most frequent double aneuploidy recognised.

In this paper a case of Down-mosaic Turner syndrome associated with congenitally dislocated knees is presented. No previous report of a similar combination could be traced.

\section{Case report}

After an uneventful pregnancy, the proband, a Caucasian female, was born weighing $3 \mathrm{~kg}$ and measuring $50 \mathrm{~cm}$ in length. The father was 28 years old and the mother 26 years at the time of the child's birth. The proband had mongoloid features (fig 1a), bilaterally dislocated knees (fig $1 \mathrm{~b}$ ), webbed neck, a transverse palmar crease, low hairline, oedema of both feet, hypoplastic nipples, and cubitus valgus. $X$-rays confirmed bilateral dislocation of her knees. She is now 5 years old and has both mental and physical retardation. She is the only child and her mother has not had any miscarriages.

Received for publication 28 April 1980

\section{CYTOGENETIC INVESTIGATIONS}

A buccal smear showed a single Barr body in $14 \%$ of the cells examined. Chromosomes from lymphocyte cultures taken from the proband and both $\bar{g}$ parents were examined in standard and trypsinGiemsa banded preparations. The proband had 46 chromosomes in $\mathbf{3 7}$ of the 50 cells analysed. In each of these cells there was an extra chromosome 21

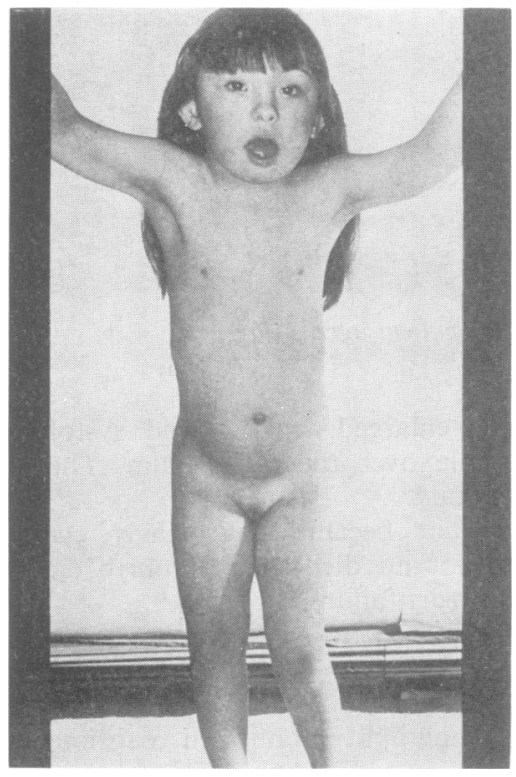

FIG 1a Proband at the age of 5 years.

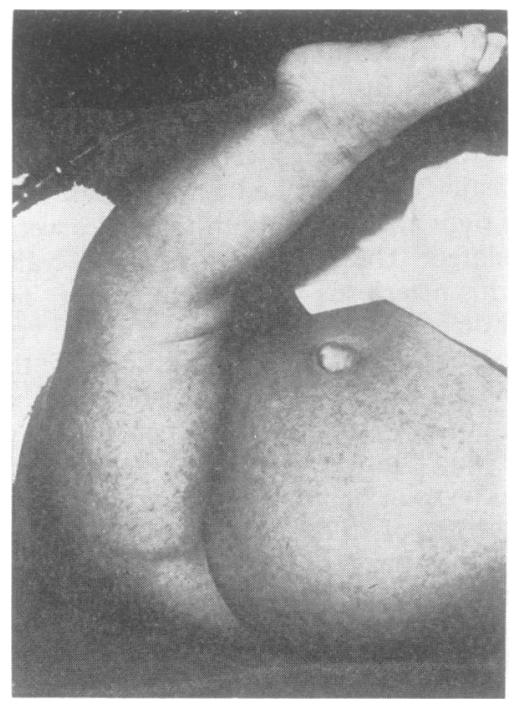

FIG $1 b$

Congenitally dislocated knees (only one shown). 


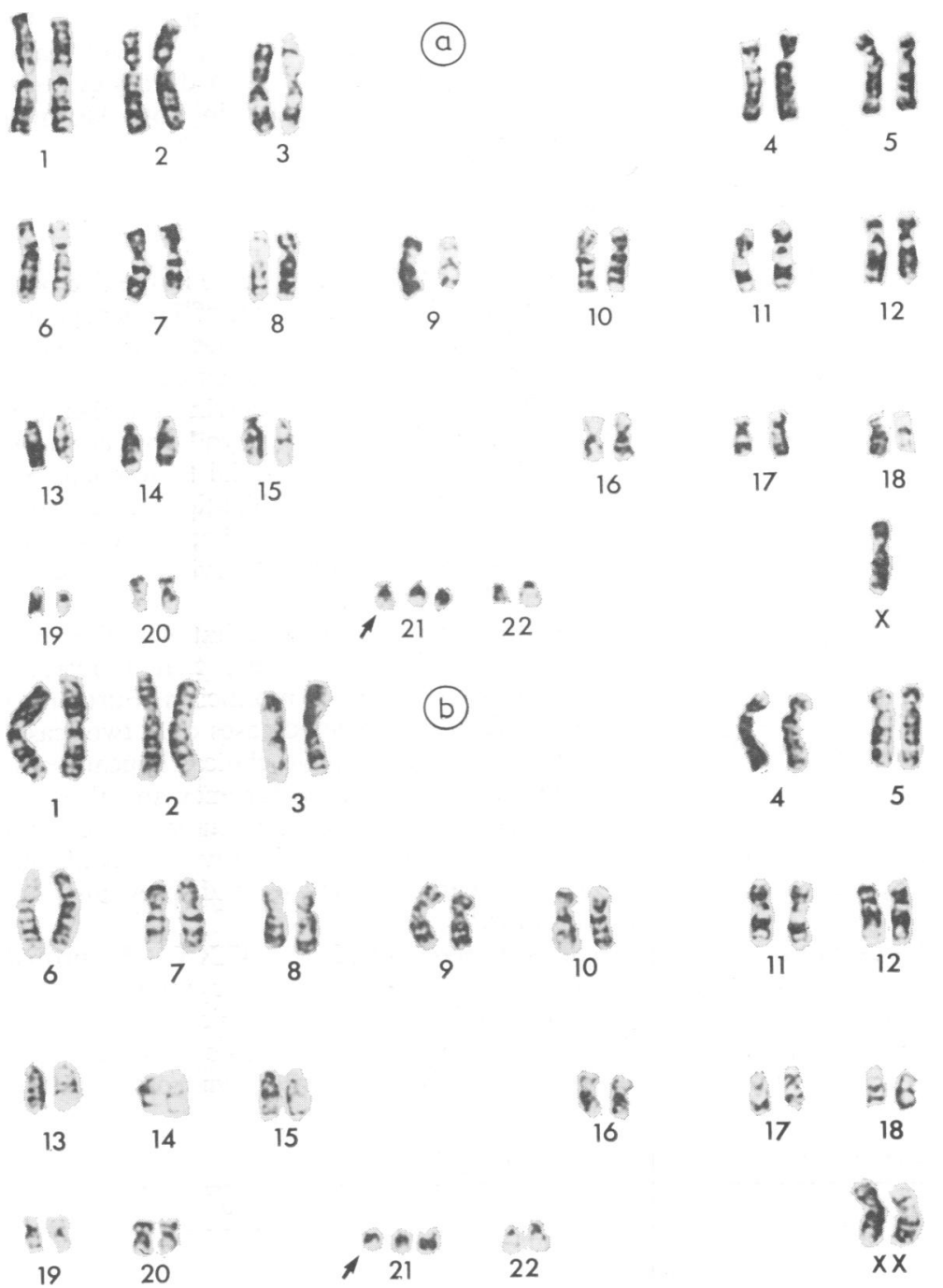

FIG 2 (a) Of 50 cells examined, 37 showed this karyotype; (b) of 50 cells examined, 13 showed this karyotype.

while one of the $\mathrm{X}$ chromosomes was missing (fig $2 \mathrm{a}$ ). The remaining 13 cells contained 47 chromosomes with an additional chromosome 21 (fig 2 b). As $75 \%$ of the cells analysed had one $\mathbf{X}$ chromosome, it is not suprising that the child had phenotypic features of both Turner and Down syndromes. Her karyotype was $46, X,+21 / 47, X X,+21$. Both parents had normal karyotypes.

DERMATOGLYPHS

The fingerprint patterns were ten ulnar loops (fig 3). The total finger ridge count, 103 ridges, was below the average figure of 126 ridges for English female controls. On the right palm there was an incomplete four-finger crease and a peripheral loop on interdigital area III. The hallucal area on the left sole showed an open field tibial arch pattern without associated $e$ or $f$ triradii. Similar features are observed in Down syndrome.

On the left palm there was a peripheral loop on area $I$. The sum of the left and right $a-b$ ridge counts, 91 ridges, was above the mean value of 85 ridges for females with Down syndrome and of 86.8 ridges for XX controls. ${ }^{2}$ On both soles there was a proximal 

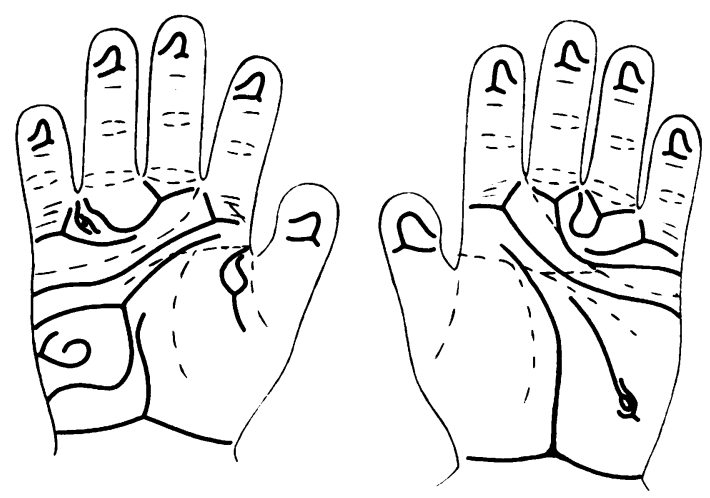

palm. Whorls occur on this region of the hand with a frequency of $26.2 \%$ in Turner syndrome and $11.9 \%$ in females with Down syndrome, but with an incidence of $2.0 \%$ in XX controls. A distal deviation of the axial triradii is observed in both Down and Turner syndromes.

\section{Discussion}

The incidence of Down syndrome in the live born is approximately 1 in 700 and that of Turner syndrome is about 1 in 5000 . If one assumes that mechanisms governing the two syndromes are separate, the expected incidence of them occurring together would be 1 in 3.5 million. As each syndrome contributes significantly to abortion material there could be an

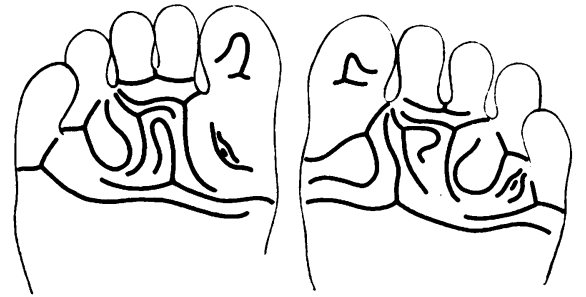

FIG 3 Dermatoglyphic pattern of palms and soles of the proband.

loop II and a zygodactylous $z$ triradius. Thenar/ first interdigital patterns, high $a-b$ ridge counts, an excess of II loops, and zygodactyly are pecularities of Turner syndrome.

The palmar configurations of this case also showed features common to both Down syndrome and single $\mathrm{X}$ females. On the hypothenar area of each palm there was a whorl. It was associated with a $t^{\prime \prime}$ triradius on the left palm and with a $t^{\prime}$ on the right increased chance of the combination being aborted. Up to the present only 17 liveborn cases could be traced in published reports. A review of these is set out briefly in the table.

From the table it is apparent that of all the cases of double aneuploidy, only one, that reported by Townes et $a l,{ }^{3}$ had no $\mathrm{X}$ mosaicism. Furthermore, of all the fully documented cases only two, case 10 and the present case, have clinical appearances of both Down and Turner syndromes and these were substantiated by cytogenetic studies. The unique feature of the present case, however, is its diagnosis at birth, the earliest diagnosis made previously being at 2 months. ${ }^{4}$

The karyotype $46, \mathrm{X},+21 / 47, \mathrm{XX},+21$ probably arose through a somatic error involving the $X$ chromosome in a patient trisomic for chromosome 21 at conception. If this were true then there should be no excess risk of Turner syndrome in further

TABLE Previously described cases of Down-Turner polysyndrome in chronological order

\begin{tabular}{|c|c|c|c|}
\hline Case & Patient report & Chromosome constitution & Clinical appearance \\
\hline $\begin{array}{r}1 \\
* 2 \\
* 3 \\
* 4 \\
* 5 \\
6 \\
7 \\
8 \\
* 9 \\
* 10 \\
11 \\
12 \\
13 \\
14 \\
15 \\
16 \\
17\end{array}$ & $\begin{array}{l}\text { Hanhardt (1960) } \\
\text { Mendis et al (1962) } \\
\text { Van Wijck et al (1964) } \\
\text { Root et al } \\
\text { Zergottern and Hoefnagel (1964) } \\
\text { Candella et al (1965) } \\
\text { Candella et al }(1966) \\
\text { Pfeiffier et al (1968) } \\
\text { Grosse et al (1971) } \\
\text { Mikel'saar et al5 } \\
\text { Villaverde et al6 } \\
\text { Villaverde et al6 } \\
\text { Villaverde et al6 } \\
\text { Townes et al3 } \\
\text { Singh et al7 } \\
\text { Singh et al7 } \\
\text { Singh et al }{ }^{7}\end{array}$ & 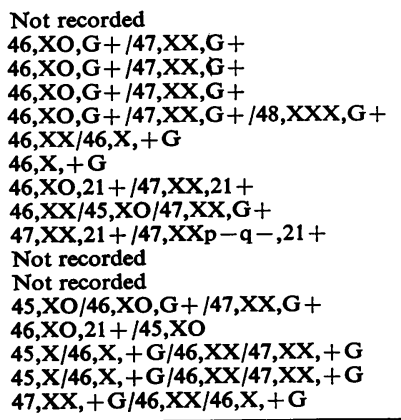 & $\begin{array}{l}\text { Down } \\
\text { Down } \\
\text { Down } \\
\text { Down } \\
\text { Down } \\
\text { Down } \\
\text { Down } \\
\text { Down } \\
\text { Down } \\
\text { Down/Turner } \\
\text { Down/Turner } \\
\text { Down/Turner } \\
\text { Down } \\
\text { Down } \\
\text { Down } \\
\text { Down } \\
\text { Down }\end{array}$ \\
\hline
\end{tabular}

Lack of uniformity in cytogenetic terminology is the result of differences in original reports.

*Cases from Townes et al. ${ }^{3}$

Case 8 quoted by Mikel'saar et al.5

Case 1 quoted by Villaverde et al. 6

Cases 6 and 7 quoted by Singh et al. 7 
children. The recurrence of Down syndrome is probably 1 in 100 and will increase with age.

The fact that clinical features of the two syndromes coexist in this patient shows the relative autonomy of these chromosomes in the determination of the processes of morphogenesis.

Congenital dislocation of the knees is 80 times less common than congenital dislocation of the hips. ${ }^{8}$ The congenital anomalies most frequently associated with it are dislocated hips and talipes equinovarus. Except in Larsen syndrome, there does not appear to be a hereditary basis.

Skeletal abnormalities such as short metacarpals, hypoplasia of the middle fifth phalanx, and clinodactyly are seen in Down syndrome, whereas cubitus valgus, medial tibial exostosis, and short fourth metacarpal are seen in Turner syndrome. There is thus a possibility that the association of the knee abnormality with the Down-mosaic Turner syndrome may not be a chance occurrence, as other skeletal defects do occur in the two syndromes.

I wish to thank Dr Saldaña-Garcia of Harperbury Hospital, Radlett, Herts, for his invaluable advice in the preparation of this manuscript, particularly in the analysis of the dermatoglyphs. I would also like to thank Dr M Super of the Department of Genetics, Royal Manchester Children's Hospital for his constructive criticism and support.

A R Gatrad Royal Manchester Children's Hospital, Pendlebury, $\mathrm{Nr}$ Manchester

\section{References}

1 Weiss L, Reynolds WA. Osseous malformations associated with chromsomal abnormalities. Orthop Clin North Am 1972;3:713-31.

2 Saldaña-Garcia P. Dermatoglyphs in sex chromosome anomalies. J Ment Defic Res 1977;23:91-104.

3 Townes PL, White MR, Stiffler SJ, Kong-oo Goh. Double aneuploidy. Am J Dis Child 1975;129:1062-5.

4 Root AW, Bongiovanni AM, Briebarts S, Mellman WJ. Double aneuploidy: trisomy 21 and $\mathrm{XO} / \mathrm{XX}$ sex chromosome mosaicism. J Pediatr 1964;65:937-9.

5 Mikel'saar AVN, Blyumina MG, Kuznetsova LI, Mikel'saar RVA, Lur'e IV. A double chromosomal aberration of the $47, X X, 21+/ 47, X X p-q-, 21+$ type in a girl with features of Down's and Turner's syndromes. Genetika 1971;5:156-61.

6 Villaverde MM, Jacynths A, Da Silva A. Turnermongolism polysyndrome, Review of the first eight known cases. JAMA 1975;234:844-7.

7 Singh DN, Osborne RA, Hennigar GR, Bornett CD. Mosaic double aneuploidy of $\mathrm{X}$ and $\mathrm{G}$ chromosomes. $\mathrm{Am}$ J Ment Defic 1975;79:644-7.

8 Kopits E. Beitrage zur Pathologic und Therapic der Angeboremen Kniegelenkssubluxatisen. Arch Orthop Unfallchir 1925;23:593-609.

Requests for reprints to Dr A R Gatrad, Department of Paediatrics, Oldham and District General Hospital, Rochdale Road, Oldham OL1 2JH.

\section{A new probably autosomal recessive cardiomelic dysplasia with mesoaxial hexadactyly}

SUMMARY A distinct probably autosomal recessive syndrome was ascertained in a 17-year-old boy and his deceased sister. The main features were cardiac dysplasia, peculiar facies, central bilateral (mesoaxial) hexadactyly, synmetacarpalia, short stature, ocular torticollis, and delayed puberty.

We describe a patient with multiple congenital anomalies, some of which were indirectly ascertained in his deceased sister, suggesting autosomal recessive inheritance.

\section{Case report}

The proband, born in 1962, was the product of a term gestation and normal delivery. Birthweight and length were not recorded; however, he was smaller than his normal sibs. Bilateral hexadactyly, broad right hallux, acrocyanosis, the presence of teeth, and dyspnoea were observed at birth. Psychomotor retardation was evident from early infancy and he tilted his head to the left when he started walking at about 4 years of age. Excision of the supernumerary right finger was performed at 10 years of age. Physical examination at $13 \frac{3}{4}$ years (fig 1) showed delayed development, a weight of $28.7 \mathrm{~kg}$, a height of $134 \mathrm{~cm}$ (both below the 3rd centile), an upper-tolower-segment ratio of $0.97(66 / 68)$, an arm span of $127 \mathrm{~cm}$, and a head circumference of $53 \mathrm{~cm}$. Other features included normocephaly, wide and flat forehead, hypotrichosis of the eyebrows distally (ulerythema ophryogenes), telecanthus, ocular torticollis as a result of alternate exophoria-tropia, a winking tick, long prominent nose with lateral bossing, tented nares, lateral pits in the nasal alae, short philtrum, macrostomia, everted lower lip, downturned mouth, multiple dental diastemata and malocclusion, large pinnae, prominent anthelix, two right Darwinian tubercles, short neck, prominent trapezius muscles, cylindrical thorax, hypoplastic nipples, underdeveloped external genitalia, normal spine, mesoaxial hexadactyly in both hands, digital clubbing and cutaneous syndactyly between digits 2 and 3, thenar and hypothenar hypoplasia, genu and pes valgus, right hallucal polysyndactyly, and mild flattening of toe nails. Dermatoglyphic analysis did not reveal extra triradii at the base of the supernumerary fingers.

Received for publication 6 May 1980 